\title{
Determinants of Body Mass Index in Turkey: A Quantile Regression Analysis from a Middle Income Country
}

\author{
Deniz Karaoğlan* \\ Bahçeşehir University
}

\author{
Aysit Tansel** \\ Middle East Technical University
}

\begin{abstract}
This study investigates the factors that may influence the individual's Body Mass Index (BMI) in the developing country of Turkey by implementing Quantile Regression (QR) methodology. The analysis is conducted by using the 2008, 2010 and 2012 waves of the Turkish Health Survey (THS) prepared by the Turkish Statistical Institute (TURKSTAT). QR regression results provide robust evidence that additional years of schooling are negatively correlated with an individual's BMI and this relationship is significantly raised across different quantiles of BMI. We also find a strong negative relationship between being in the labor force and an individual's BMI, and this relationship increases across the quantiles of BMI implying that an individual is more likely to be obese if he/ she is out of labor force. Our results suggest that other socioeconomic and demographic indicators such as gender, age, marital status and household income are also important factors to explain the variation in an individual's BMI.
\end{abstract}

Keywords: obesity; adults; BMI; quantile regression; Turkey

JEL Classifications: I12, I18, C21

\section{Türkiye'de Vücut Kitle İndeksi Belirleyicileri: Orta Gelirli bir Ülke için Kantil Regresyon Analizi}

\section{Özet}

Bu çalışma, bireyin Vücut Kitle İndeksini (VKI) etkileyebilecek faktörleri kantil regresyon (KR) metodolojisi uygulayarak gelişmekte olan bir ülke olan Türkiye için araştırmaktadır. Analiz, Türkiye İstatistik Kurumu (TÜİK) tarafindan hazırlanan Türkiye Sağlık Anketi'nin (TSA) 2008, 2010 ve 2012 veri setleri kullanılarak gerçekleştirilmiştir. KR sonuçları, kişinin eğitim seviyesi ve VKİ'si arasında negatif bir ilişki olduğunu açıkça göstermektedir. Bulduğumuz negatif ilişkinin VKI'nin yüksek kantillerinde daha güçlü olması sebebi ile, yüksek eğitim seviyesine sahip insanların obez veya aşırı kilolu olma olasılığının daha düşük olduğu sonucuna ulaşılmıştır. Çalışmada

* Deniz Karaoğlan is an Assistant Professor in the Department of Economics at Bahcesehir University, Çırağan Caddesi, No.4, Beşiktaş, Istanbul, Turkey. E-mail: hanifedeniz.karaoglan@eas.bau.edu.tr

** Aysit Tansel is a Professor in the Department of economics at Middle East Technical University, Dumlupınar Bulvarı No:1, 06800, Cankaya, Ankara, Turkey. E-mail: atansel@metu.edu.tr 
ayrıca bireyin işgücünde olması ve bireyin VKİsi arasında anlamlı bir negatif ilişki olduğu sonucuna ulaşılmıştır. Negatif ilişkinin VKI'nin artan kantillerinde daha güçlü olması, bireyin işgücünün dışında kaldığında obez veya aşırı kilolu olma olasılığının daha yüksek olduğu anlamına gelmektedir. Çalışmanın bulguları cinsiyet, yaş, medeni durum ve hanehalkı geliri gibi diğer sosyoekonomik ve demografik faktörlerin kişinin VKİ'sindeki varyasyonları açıklamada önemli olduklarını göstermektedir.

Anahtar Kelimeler: Obezite; yetişkinler; VKI; kantil regresyon; Türkiye JEL Siniflandirmasi: I12, I18, C21

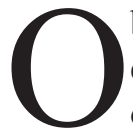
besity is the second most important health behavior after smoking that is widely examined in the health economics literature. Nevertheless, the number of studies on obesity is higher than the number of studies on smoking in recent decades. This is because the prevalence of smoking has decreased over the years, while at the same time obesity became an important health problem, not only in the USA but also in other developed countries. The recent research suggests that obesity seriously threatens the lives of individuals. Following the increase in obesity rates, and the simultaneous decrease in smoking rates in the USA in the past 30 years, Stewart et al. (2009) forecast the life expectancy and quality adjusted life expectancy for an 18 year-old individual. They find that the benefits of the decline in smoking rates, unfortunately, cannot beat the negative impacts of increased obesity rates. Their results are robust for multiple scenarios and different projections.

There are several studies that examine the determinants of obesity. The determinants of obesity generally considered are age, gender, education level, level of income and labor market status. Among all these factors, the association between education level and obesity is the most widely studied topic. Yet while there are many studies on this topic in developed countries, there are fewer studies focusing on developing countries. In this paper, we examine the determinants of an individual's Body Mass Index (BMI), a worldwide tool of detecting the risk of obesity, in Turkey, which is a middle income, developing country. Previously, Brunello et al. (2013), Webbink et al. (2010), Kemptner et al. (2011), Jürges et al. (2011) and Arendt (2005) have all examined the causal effect of education on the probability of being overweight/obese and/or on an individual's BMI levels. In these studies, the impact of education is contradictory. For instance, Brunello et al. (2013) find evidence that the impact of years of schooling is negatively significant for women in all the countries they examine, whereas it is insignificant for men in most of the countries. ${ }^{[1]}$ In contrast, Webbink et al. (2010) find that in Australia having higher levels of education reduces the risk of obesity for men; for women, however, they do not find a significant relationship between education and obesity. Kemptner et al. (2011) find that an increase in the years of schooling decreases the likelihood of being obese for both men and women in West-Germany. However, Jürges et al. (2011) do not find

[1] These countries are Austria, Denmark, Germany, Greece, Italy, Portugal, Spain, Sweden and United Kingdom. 
a significant association between education and the probability of being overweight or obese in West-Germany. Arendt (2005) provides evidence that years of education and normal ranges of BMI have a negative relationship in Denmark. Therefore, one can conclude that previous literature suggests mixed evidence for the causal effect of education on BMI levels

There are a few studies that investigate the determinants of obesity in Turkey; for example, Erem et al. (2004), Hatemi et al. (2003) and Yumuk (2005). All of these studies concentrate on specific regions of Turkey, and thus one cannot infer a general conclusion regarding the determinants of obesity in Turkey. Nevertheless, all of these studies draw attention to the increasing trend in obesity in Turkey. In fact, currently the Ministry of Health has started a campaign against obesity, offering warnings and information on the billboards of hospitals.

To our knowledge, Tansel and Karaoğlan (2014) is the first study that examines the determinants of health related behaviors in Turkey by using a rich micro data set, namely the Turkish Health Survey (THS) prepared by the Turkish Statistical Institute (TURKSTAT). In that study, in addition to other health behaviors, such as smoking and alcohol consumption, the authors examine the determinants of individuals' BMI in Turkey. Next, using Instrumental Variable (IV) methodology, Tansel and Karaoğlan (2016) examine the causal effect of education on health behaviors and BMI levels by using the same data set as this study. Cesur et al. (2014) also test the causal effect of education on health behaviors and health outcomes by using the same data set, and find that increase in education level increases the probability of being obese.

All of those studies perform their analysis by using either the Ordinary Least Squares (OLS) or the Two-Stage Least Squares (2SLS) technique. It is important to note that both the OLS and the 2SLS estimation processes give the effect of covariates upon the mean of the dependent variable or the BMI. This overlooks the fact that covariates are not homogeneous across the distribution of BMI and their effect may differ across the quantiles of BMI. Therefore, in this paper, we reinvestigate the determinants of BMI by using the quantile regression (QR) technique developed by Koenker and Basset (1978). This is expected to reveal a more robust relationship between individual's demographic characteristics and BMI. By implementing the QR methodology, our objective is to see how socio-economic and demographic factors affect the individual's BMI at different quantiles of the distribution of BMI. This paper is the first paper that uses a QR approach to examine the determinants of obesity in Turkey, conducted with a large micro data set. It will moreover be worthwhile to see the different impacts of various factors on individual's BMI at different quantiles of BMI for policy purposes.

$\mathrm{QR}$ is a rather popular method in recent health economics literature. For instance, Costa-Font et al. (2009) use it to examine the BMI gaps among women in Spain and Italy, and Villar and Quintana-Domeque (2009) to investigate the association between household income (along with other factors) and BMI in nine European countries. ${ }^{[2]}$ In a different study Atella et al. (2008) examine the impact of BMI on wages across the

[2] The countries they analyze are Austria, Belgium, Denmark, Finland, Greece, Ireland, Italy, Portugal and Spain 
different quantiles of the wage distribution for nine $\mathrm{e}^{[3]}$ countries using European Community Household Panel data for the period 1998-2001.

Our results suggest that there is negative relationship between years of schooling and BMI level. This negative association considerably increases at higher quantiles of BMI. QR results provide mixed evidence for gender and BMI relationship: we observe that at lower quantiles of BMI the association is positive, whereas at higher quantiles, the association is negative. This finding stresses the fact that women have a higher tendency to be obese relative to men. However, QR results show that at median men have higher BMI levels, indicating that being overweight is more common among men. Age and BMI level has an inverted U-shape relationship across the quantiles which reaches a high level at the top quantiles. Therefore, one can conclude that obesity is higher at older ages. In accounting for place of residence, we observe that individuals tend to have higher BMI levels in urban areas. However, the significance of this variable in the top two quantiles disappears, indicating that the prevalence of obesity does not significantly differ between urban and rural areas. Regarding marital status, we find that single individuals are less obese or overweight than the widowed/divorced and this relationship increases systematically across the quantiles of BMI. Our results also provide robust evidence for the negative relationship between being married and individual's BMI starting from the median. Moreover, the negative association rises across quantiles. Hence, the prevalence of being overweight or obese is less common among the married compared to the widowed/divorced. Inactive individuals tend to have higher BMI levels compared to employed or unemployed individuals and the magnitude of the relationship is higher at the top quantiles. Finally, our results provide robust evidence that household income has a positive association with BMI at all quantiles.

This paper contributes to the literature in the following dimensions: first, it is one of the few papers that examines the determinants of BMI in developing countries. Second, it differs from previous studies on obesity in Turkey in adopting quantile regression methodology, which has been used in studies of BMI index in other, mostly developed, countries. Finally, it is the first paper on Turkey that focuses solely on the determinants of individual's BMI index by using a rich, representative cross-sectional data set.

\section{Literature Review}

The reasons behind the rise in obesity have been examined by several authors, especially with regard to the USA, where prevalence of obesity is rather high, at 36.5 per cent of its population in $2014 .{ }^{[4]}$ These studies conclude that rising obesity can be attributed to several factors, such as higher participation rates among the female labor force (Chou et al., 2002), reduction in smoking (Chou et al., 2002; Rashad and Grossman, 2004), the rise in the number of fast food restaurants (Chou et al., 2002; Rashad and Grossman, 2004; Phillipson and Posner, 2008), technological improvement (Cutler et al., 2003;

\footnotetext{
[3] The countries they examine are the same in Villar and Quintina-Domeque (2009).

${ }^{[4]}$ Source: Center of Disease Control (CDC): https://www.cdc.gov/nchs/data/databriefs/db219.pdf
} 
Philipson and Posner, 2003; Rashad and Grossman, 2004), increased caloric intake due to more affordable prices (Rashad and Grossman, 2004), decline in physical activity (Rashad and Grossman,2004), switching from agricultural economies to industrial ones (Phillipson and Posner, 2008), and rise in income level (Phillipson and Posner, 2008). ${ }^{[5]}$

Socio-economic determinants of obesity are studied mostly through the lens of developed countries, but there is less research on obesity in developing countries. Literature on developed countries has confirmed the fact that improvement in macro level variables such as education expenditures per capita and number of physicians per capita, leads to greater health outcomes (Llearas-Muney, 2005). In fact, most of the studies on developed countries show that increase in the level of socioeconomic status (SES) variables, namely education and income, causes an improvement in health related variables, including a decline in the probability of being obese (Webbink et al., 2010, Kemptner et al., 2011). However, due to lower income, lower education levels and scarcer health services in developing countries, we expect that the relationship between SES and health outcomes, including obesity, will differ between developing countries and developed countries.

The literature on developing countries, in fact, suggests contradictory results regarding the determinants of obesity. For instance, Fernald (2007) finds that higher education levels are associated with higher BMI levels in Mexico. Aekplakorn et al. (2014) conclude that as economic growth increases, obesity becomes more widespread among individuals belonging to lower SES in Thailand. Dinsa et al. (2012) examine the relationship between SES and obesity in low and middle income countries. Their results indicate that individuals belonging to higher SES are more likely to be obese in low-income countries. For middle income countries, the evidence for men is mixed, while for women, there is a negative association between SES and the probability of being obese.

Regarding Turkey, earlier studies of obesity have been conducted on a regional basis (Erem et al., 2004; Hatemi et al., 2003 and Yumuk, 2005), and thus their results may reflect regional variation. For instance, Erem et al. (2004) conduct their study in Trabzon. Their results indicate that the prevalence of obesity is higher among women than men. Their results also suggest that obesity is positively related to being married, giving up smoking, alcohol consumption, and household income and inversely related with level of education, cigarette use and physical activity. They conclude that obesity is also positively associated with hypertension. Hatemi et al. (2003) investigate the determinants of obesity for just 11 cities in Turkey, and provide similar results. Furthermore, the authors likewise stress that being obese or overweight constitute risk factors for hypertension. Compared to the previous two studies, Yumuk (2005) conducts his analysis on a richer sample set, as he concentrates on 59 randomly selected cities in different regions of Turkey. The study provides descriptive statistics about the determinants of obesity, and shows that men are more likely to be overweight, whereas women are more likely to be obese.

[5] The authors conclude that increase in income leads to increase in weight among the poorest groups, but it leads to a decrease in weight throughout the upper half of the income distribution 
Tansel and Karaoğlan (2014) conducted the first study that examines the determinants of health behaviors and BMI by using a rich, cross-sectional data set, the same rounds of the THS data set as this study. The authors find that BMI levels decrease as education levels increase. In addition, they find that women have significantly higher levels of BMI than men, urban populations have higher BMI levels than rural populations, and BMI levels of widowed/divorced individuals are significantly lower than either married or single individuals. Finally, they argue that both employed and unemployed individuals have lower BMI levels than those who are out of labor force, and they find a positive association between individual's BMI level and household income.

In a more recent study using Instrumental Variable (IV) methodology, Tansel and Karaoğlan (2016) examine the causal effect of education on individual's BMI levels by using the same data set as this study. They take the education expansion of the early 1960s in Turkey as an instrument for education and, similar to Fernald et al. (2007), the authors find that education is correlated with an increase in BMI level. Cesur et al. (2014) also examine the causal effect of education on various health behaviors and health outcomes, including obesity, by using the same waves of the THS data set. The authors find that men who are between 18 and 30 years old with higher levels of education are more likely to be obese or overweight than the less educated in Turkey.

In a recent study, Ankara (2016) analyzes socioeconomic determinants of obesity in Turkey for women at fertility age by using the 2008 round of the Turkish Demographic Health Survey (TDHS) data set. The results indicate that wealthier women are more likely to be obese in eastern regions, whereas obesity is more prevalent among poorer women in western regions. The author concludes that wealth and ethnicity are the most important factors that explain the inequality in obesity among women in Turkey.

\section{Data and Methodology}

In this study, we use the Turkish Health Survey Data Set (THS) for the years 2008, 2010 and 2012. THS is a cross sectional data set over individuals. It is prepared and conducted by the Turkish Statistical Institute (TURKSTAT).${ }^{[6]}$ Regarding the descriptive statistics of covariates, we do not detect any significant differences between these three data sets. Therefore, we pool the data sets and conduct the empirical analysis of this study. ${ }^{[7]}$ In this survey health related questions are asked separately for 3 different age groups, namely $0-6,7-14$, and 15 or above. We concentrate on individuals above 25 in order to circumvent the problem of incomplete education, since in Turkey, individuals finish their schooling approximately at the age of 25 . The pooled data set contains 46,473 individuals over 25 years old.

In THS, demographic information on respondents over 25 , such as age, gender, education level, marital status, household income, place of residence (urban/rural) and

\footnotetext{
[6] Although both the 2014 and 2016 survey data are available to us, we prefer not to use them in this study, because the change in the design of the questionnaire makes compatibility with earlier years difficult.

[7] Seperate analysis of the 2008, 2010 and 2012 surveys are available from authors upon request.
} 
labor market status (employed, unemployed or inactive), are available. Individuals' self-reported age (in continuous terms) is available in the THS data set. We use this information directly in our empirical analysis. For gender, we define a dummy variable, which is equal to 1 if the individual is male, and 0 if the individual is female. We group the marital statuses of the respondents as married, single and widowed/divorced.

The variable "Years of Schooling" is constructed in the following manner: if an individual is illiterate, we assume that his/her years of schooling is equal to 0 . Next, if an individual is literate but has not graduated from any school then his/her years of schooling is given a value of 2 . An individual's years of schooling is given a value of 5,8 and 11 if he/she has completed primary, middle and high schools respectively. Finally, an individual's years of schooling is equal to 15 if he/she has attained a degree at the college/university level or higher. We considered three employment statuses as employed, unemployed and inactive. The respondents who state that they have a regular job are referred to as "employed", whereas respondents who state that they are not working but looking for work are referred to as "unemployed". The respondents who state that they are seasonal workers, students, housewives or pensioners, and those who state that they are not able to work are considered "inactive." Next, in THS the respondents are asked to tell or (if they do not know) guess their monthly net household income. The income categories are divided into 11 groups. These are: "Less than 350 Turkish Liras (TL), 351-500 TL, 501-620 TL, 621-750 TL, 751-900 TL, 901-1100 TL, 1101-1300 TL, 1301-1700 TL, 1701-2300 TL, More than 2301 TL, I do not want to answer this question". We take the mid-points of each group and determine the individual's household income accordingly. In the empirical analysis we use the logarithm of household income as a proxy for an individual's income since this information is not available in the THS data sets.

The indicator for obesity/overweight is the individual's Body Mass Index (BMI), which can be found by dividing the self-reported weight (in kilograms) by the square of self-reported height (in meters). We report the observation as missing, if an individual does not report his/her height and/or weight. ${ }^{[8]}$ Therefore, we are left with 41,074 observations. The descriptive statistics for four different BMI groups (underweight/normal/ overweight/obese) as well as the statistics for BMI is presented in Table 1.

${ }^{[8]} 11.65$ per cent of the individuals in the data set do not report their height or weight. 
Table 1

\section{Descriptive Statistics for BMI}

\begin{tabular}{|c|c|c|c|c|c|}
\hline Variable & $\begin{array}{l}\text { Underweight } \\
(\mathrm{BMI}<\mathbf{1 8 . 5})\end{array}$ & $\begin{array}{l}\text { Normal Weight } \\
(18.5<=\text { BMI }<=24.99)\end{array}$ & $\begin{array}{l}\text { Overweight } \\
(25<=\mathrm{BMI}<30)\end{array}$ & $\begin{array}{l}\text { Obese } \\
(\text { BMI>=30) }\end{array}$ & Total \\
\hline Male* & $\begin{array}{c}0.01 \\
(0.10)\end{array}$ & $\begin{array}{c}0.37 \\
(0.48)\end{array}$ & $\begin{array}{c}0.45 \\
(0.50)\end{array}$ & $\begin{array}{c}0.17 \\
(0.38)\end{array}$ & 1.00 \\
\hline Female* & $\begin{array}{c}0.02 \\
(0.15)\end{array}$ & $\begin{array}{c}0.38 \\
(0.48)\end{array}$ & $\begin{array}{c}0.34 \\
(0.47)\end{array}$ & $\begin{array}{c}0.26 \\
(0.44)\end{array}$ & 1.00 \\
\hline Age (Years) & $\begin{array}{l}42.57 \\
(16.79)\end{array}$ & $\begin{array}{c}43.77 \\
(14.96)\end{array}$ & $\begin{array}{c}47.47 \\
(13.94)\end{array}$ & $\begin{array}{c}50.51 \\
(13.08)\end{array}$ & $\begin{array}{l}46.65 \\
(14.44)\end{array}$ \\
\hline Age-Squared & $\begin{array}{c}2093 \\
(1759)\end{array}$ & $\begin{array}{c}2139 \\
(1534)\end{array}$ & $\begin{array}{c}2447 \\
(1443)\end{array}$ & $\begin{array}{c}2722 \\
(1385)\end{array}$ & $\begin{array}{c}2385 \\
(1489)\end{array}$ \\
\hline Urban* & $\begin{array}{c}0.02 \\
(0.13)\end{array}$ & $\begin{array}{c}0.37 \\
(0.48)\end{array}$ & $\begin{array}{c}0.39 \\
(0.49)\end{array}$ & $\begin{array}{c}0.22 \\
(0.41)\end{array}$ & 1.00 \\
\hline Rural* & $\begin{array}{c}0.02 \\
(0.14)\end{array}$ & $\begin{array}{c}0.37 \\
(0.48)\end{array}$ & $\begin{array}{c}0.39 \\
(0.48)\end{array}$ & $\begin{array}{c}0.22 \\
(0.41)\end{array}$ & 1.00 \\
\hline
\end{tabular}

\begin{tabular}{|c|c|c|c|c|c|}
\hline \multicolumn{6}{|c|}{ Marital Status } \\
\hline Married* & $\begin{array}{c}0.01 \\
(0.12)\end{array}$ & $\begin{array}{c}0.35 \\
(0.48)\end{array}$ & $\begin{array}{c}0.41 \\
(0.49)\end{array}$ & $\begin{array}{c}0.23 \\
(0.42)\end{array}$ & 1.00 \\
\hline Single* & $\begin{array}{c}0.05 \\
(0.23)\end{array}$ & $\begin{array}{c}0.62 \\
(0.49)\end{array}$ & $\begin{array}{c}0.25 \\
(0.44)\end{array}$ & $\begin{array}{c}0.08 \\
(0.26)\end{array}$ & 1.00 \\
\hline $\begin{array}{l}\text { Widowed/ } \\
\text { Divorced* }\end{array}$ & $\begin{array}{c}0.02 \\
(0.14)\end{array}$ & $\begin{array}{c}0.35 \\
(0.48)\end{array}$ & $\begin{array}{c}0.35 \\
(0.48)\end{array}$ & $\begin{array}{c}0.28 \\
(0.45)\end{array}$ & 1.00 \\
\hline \multicolumn{6}{|c|}{ Education } \\
\hline Years of Schooling & $\begin{array}{c}7.73 \\
(4.82)\end{array}$ & $\begin{array}{c}7.56 \\
(4.54)\end{array}$ & $\begin{array}{c}6.99 \\
(4.30)\end{array}$ & $\begin{array}{c}5.81 \\
(4.02)\end{array}$ & $\begin{array}{c}6.96 \\
(4.39)\end{array}$ \\
\hline $\begin{array}{l}\text { Years of } \\
\text { Schooling-Squared }\end{array}$ & $\begin{array}{c}82.87 \\
(80.44)\end{array}$ & $\begin{array}{c}77.77 \\
(76.78)\end{array}$ & $\begin{array}{c}67.39 \\
(71.75)\end{array}$ & $\begin{array}{c}49.98 \\
(61.99)\end{array}$ & $\begin{array}{c}67.78 \\
(72.65)\end{array}$ \\
\hline
\end{tabular}

\begin{tabular}{|c|c|c|c|c|c|}
\hline \multicolumn{6}{|c|}{ Labor Market Status } \\
\hline Employed* & $\begin{array}{c}0.02 \\
(0.13)\end{array}$ & $\begin{array}{c}0.41 \\
(0.49)\end{array}$ & $\begin{array}{c}0.41 \\
(0.49)\end{array}$ & $\begin{array}{c}0.16 \\
(0.37)\end{array}$ & 1.00 \\
\hline Unemployed* & $\begin{array}{c}0.03 \\
(0.17)\end{array}$ & $\begin{array}{c}0.53 \\
(0.50)\end{array}$ & $\begin{array}{c}0.35 \\
(0.48)\end{array}$ & $\begin{array}{c}0.09 \\
(0.28)\end{array}$ & 1.00 \\
\hline $\begin{array}{l}\text { Out of Labor } \\
\text { Force* }\end{array}$ & $\begin{array}{c}0.02 \\
(0.14)\end{array}$ & $\begin{array}{c}0.34 \\
(0.47)\end{array}$ & $\begin{array}{c}0.38 \\
(0.48) \\
\end{array}$ & $\begin{array}{c}0.26 \\
(0.44) \\
\end{array}$ & 1.00 \\
\hline $\begin{array}{l}\text { Log Household } \\
\text { Income (TL) }\end{array}$ & $\begin{array}{c}6.88 \\
(0.64)\end{array}$ & $\begin{array}{c}6.95 \\
(0.63)\end{array}$ & $\begin{array}{c}6.98 \\
(0.59)\end{array}$ & $\begin{array}{c}6.95 \\
(0.59)\end{array}$ & $\begin{array}{c}6.96 \\
(0.61)\end{array}$ \\
\hline No. of Obs. in 2008 & 209 & 3998 & 3764 & 1943 & 9914 \\
\hline No. of Obs. in 2010 & 201 & 3844 & 3928 & 2317 & 10290 \\
\hline No. of Obs. in 2012 & 322 & 7570 & 8331 & 4647 & 20870 \\
\hline Total No. Of Obs. & 732 & 15412 & 16023 & 8907 & 41074 \\
\hline
\end{tabular}

Source: Authors' computations using 2008, 2010 and 2012 Turkish Health Surveys

Notes: (1)*indicates a dummy variable

(2) The numbers in the paranthesis are standard deviations 
We observe in Table 1 that average years of schooling is lower among obese individuals. Women seem to be more obese than men and men seem to be more overweight than women. The prevalence of obesity increases as the individual gets older. We do not find significant variation in the weight ranges of urban and rural residents. Married individuals seem to be more overweight, whereas widowed/divorced individuals seem to be more obese relative to other marital status groups. Descriptive statistics also suggest that the occurrence of obesity is higher among inactive individuals and the household income is slightly higher among overweight individuals.

In this study, we conduct Quantile Regression $(\mathrm{QR})$ analysis. By applying this methodology, we are able to examine how the covariates considered affect the BMI at different quantiles of the distribution of BMI. As a result, we are able to get an extensive view of the effects of the determinants of BMI. Apart from providing more general results, QR has other advantages over OLS. For instance, quantile regression offers a more robust interpretation of outliers than OLS. In addition, unlike OLS, we do not need to make strong stochastic assumptions in quantile regressions (See Cameron and Trivedi, 2005 , p. 85). In order to have more consistent standard errors we used bootstrapped techniques $^{[9]}$ as suggested by Koenker and Hallock (2001). Table 2 presents both the levels and 95 per cent confidence intervals for the distribution of BMI levels at different quantiles $\left(5^{\text {th }}, 10^{\text {th }}, 25^{\text {th }}, 50^{\text {th }}, 75^{\text {th }}, 90^{\text {th }}, 95^{\text {th }}\right.$ Quantiles $)$. Table 2 reveals that the median and $75^{\text {th }}$ Quantile include levels of BMI that indicate persons who are overweight, and the highest two quantiles include the levels of BMI that indicate obesity. In addition, Figure 1 shows the quantile plot for the distribution of BMI.

Table 2

Distribution of BMI levels at Different Quantiles

\begin{tabular}{l|l|l}
\hline Quantiles & BMI Level & $\begin{array}{l}\text { Confidence Interval for BMI } \\
\text { Level }(95 \% \text { Confidence Level) }\end{array}$ \\
\hline $5^{\text {th }}$ Quantile & 19.92 & $19.83-20$ \\
\hline $10^{\text {th }}$ Quantile & 21.09 & $21.04-21.21$ \\
\hline $25^{\text {th }}$ Quantile & 23.43 & $23.44-23.46$ \\
\hline $50^{\text {th }}$ Quantile & 26.17 & $26.12-26.22$ \\
\hline $75^{\text {th }}$ Quantile & 29.38 & $29.384-29.387$ \\
\hline $90^{\text {th }}$ Quantile & 32.91 & $32.87-33.05$ \\
\hline $95^{\text {th }}$ Quantile & 35.15 & $35.15-35.32$ \\
\hline Number of Observations & 41074 & \\
\hline
\end{tabular}

Source: Authors' computations using 2008, 2010 and 2012 Turkish Health Surveys

[9] We replicated the bootstrapped quantile regressions 400 times to get more robust results. 
Figure 1

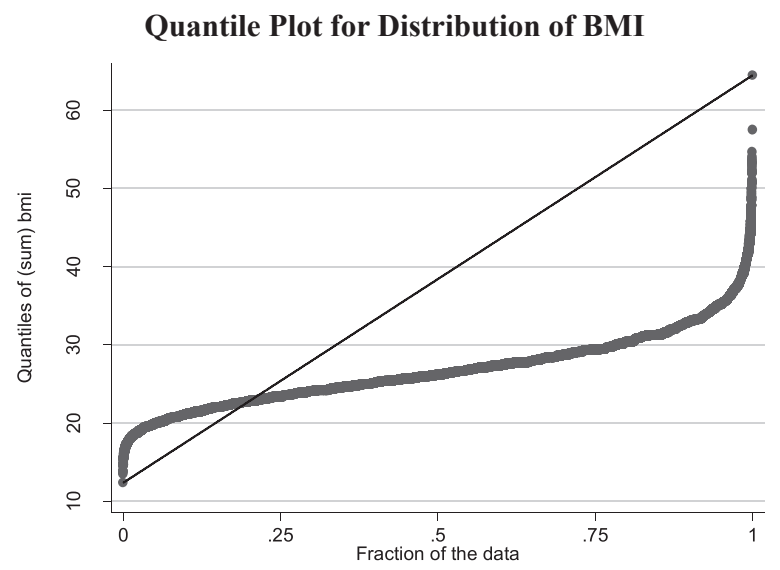

Based on the previous literature, we establish our model as follows:

$$
Q_{B M I, \tau}=\beta_{0}+X_{i}^{\prime} \beta_{1}(\tau)+\varepsilon_{i}(\tau)
$$

In equation (1), $\tau$ corresponds to the $\tau^{\text {th }}$ Quantile of BMI distribution. Hence, refers to the individual's BMI in the $\tau^{\text {th }}$ Quantile. The vector X includes individual's demographic and socio-economic characteristics such as education, gender, age, place of residence, marital status, labor market status, and household income. The vector also consists of dummies for each separate year, where the year 2008 is the omitted category. Hence, we are able to observe survey year effects in the empirical analysis. Therefore, $\beta_{1}(\tau)$ shows the effect of an individual's demographic and socio-economic characteristics on his/her BMI in the $\tau^{\text {th }}$ Quantile. In addition, $\beta_{1}(\tau)$ also shows the year effect on an individual's BMI. Finally, refers to the unobserved factors in each quantile $\tau$, such as genetics.

\section{Results}

Table 3 presents both the OLS estimation and the QR estimation results. The QR is estimated for the $5^{\text {th }}, 10^{\text {th }}, 25^{\text {th }}, 50^{\text {th }}, 75^{\text {th }}, 90^{\text {th }}$, and $95^{\text {th }}$ Quantiles of the BMI distribution. One should be careful in interpreting our estimated coefficients in the sense that they do not provide a causal relationship; rather they show the controlled associations between each control variable and individuals' BMI at different quantiles of BMI. 
Table 3

\section{OLS and Quantile Regression Results (Dependent Variable: Individual's BMI)}

\begin{tabular}{|c|c|c|c|c|c|c|c|c|}
\hline Variable & OLS & Q5 & Q10 & Q25 & Q50 & Q75 & Q90 & Q95 \\
\hline \multicolumn{9}{|c|}{ Education } \\
\hline Years of Schooling & $\begin{array}{l}-0.10 * * * \\
(0.02)\end{array}$ & $\begin{array}{l}-0.03 \\
(0.03)\end{array}$ & $\begin{array}{l}-0.003 \\
(0.03)\end{array}$ & $\begin{array}{l}-0.05^{* *} \\
(0.03)\end{array}$ & $\begin{array}{l}-0.13 * * * \\
(0.03)\end{array}$ & $\begin{array}{l}-0.14 * * * \\
(0.03)\end{array}$ & $\begin{array}{l}-0.22 * * * \\
(0.04)\end{array}$ & $\begin{array}{l}-0.19^{* * *} \\
(0.06)\end{array}$ \\
\hline $\begin{array}{l}\text { Years of } \\
\text { Schooling- Squared }\end{array}$ & $\begin{array}{l}-0.002 \\
(0.001)\end{array}$ & $\begin{array}{l}-0.002 \\
(0.001)\end{array}$ & $\begin{array}{l}-0.004 * * \\
(0.001)\end{array}$ & $\begin{array}{l}-0.002 \\
(0.002)\end{array}$ & $\begin{array}{l}0.0004 \\
(0.001)\end{array}$ & $\begin{array}{l}-0.0004 \\
(0.001)\end{array}$ & $\begin{array}{l}0.003 \\
(0.002)\end{array}$ & $\begin{array}{l}0.0004 \\
(0.003)\end{array}$ \\
\hline \multicolumn{9}{|c|}{ Demographic Factors } \\
\hline Male & $\begin{array}{l}-0.10^{*} \\
(0.05)\end{array}$ & $\begin{array}{l}0.79^{* * *} \\
(0.07)\end{array}$ & $\begin{array}{l}0.83^{* * *} \\
(0.07)\end{array}$ & $\begin{array}{l}0.76^{* * * *} \\
(0.06) \\
\end{array}$ & $\begin{array}{l}0.38 * * * \\
(0.06) \\
\end{array}$ & $\begin{array}{l}-0.34^{* * * *} \\
(0.09)\end{array}$ & $\begin{array}{l}-1.27 * * * \\
(0.12)\end{array}$ & $\begin{array}{l}-1.71 * * * \\
(0.19)\end{array}$ \\
\hline $\operatorname{Age}\left(x_{10}^{-1}\right)$ & $\begin{array}{l}4.54^{* * * *} \\
(0.10)\end{array}$ & $\begin{array}{l}2.93 * * * \\
(0.15)\end{array}$ & $\begin{array}{l}3.21 * * * \\
(0.15)\end{array}$ & $\begin{array}{l}3.88^{* * * *} \\
(0.11)\end{array}$ & $\begin{array}{l}4.42^{* * * *} \\
(0.11)\end{array}$ & $\begin{array}{l}4.88^{* * * *} \\
(0.15)\end{array}$ & $\begin{array}{l}5.34 * * * \\
(0.21)\end{array}$ & $\begin{array}{l}5.41 * * * \\
(0.32)\end{array}$ \\
\hline Age Square $\left(\times 10^{-3}\right)$ & $\begin{array}{l}-4.11^{* * * *} \\
(0.10)\end{array}$ & $\begin{array}{l}-2.76 * * * \\
(0.15)\end{array}$ & $\begin{array}{l}-2.94 * * * \\
(0.16)\end{array}$ & $\begin{array}{l}-3.56^{* * * *} \\
(0.11)\end{array}$ & $\begin{array}{l}-4.01 * * * \\
(0.11)\end{array}$ & $\begin{array}{l}-4.39 * * * \\
(0.15)\end{array}$ & $\begin{array}{l}-4.81 * * * \\
(0.20)\end{array}$ & $\begin{array}{l}-4.84 * * * \\
(0.32)\end{array}$ \\
\hline Urban & $\begin{array}{l}0.30^{* * *} \\
(0.05)\end{array}$ & $\begin{array}{l}0.25^{* * * *} \\
(0.08) \\
\end{array}$ & $\begin{array}{l}0.30 * * * \\
(0.07)\end{array}$ & $\begin{array}{l}0.28 * * * \\
(0.06)\end{array}$ & $\begin{array}{l}0.26 * * * \\
(0.06) \\
\end{array}$ & $\begin{array}{l}0.27 * * * \\
(0.07)\end{array}$ & $\begin{array}{l}0.16 \\
(0.10)\end{array}$ & $\begin{array}{l}0.25 \\
(0.16)\end{array}$ \\
\hline \multicolumn{9}{|c|}{ Marital Status } \\
\hline Married & $\begin{array}{l}-0.30 * * * \\
(0.10)\end{array}$ & $\begin{array}{l}0.06 \\
(0.13)\end{array}$ & $\begin{array}{l}0.12 \\
(0.11)\end{array}$ & $\begin{array}{l}-0.13 \\
(0.10)\end{array}$ & $\begin{array}{l}-0.19^{*} \\
(0.11)\end{array}$ & $\begin{array}{l}-0.59 * * * \\
(0.15)\end{array}$ & $\begin{array}{l}-0.59 * * * \\
(0.23)\end{array}$ & $\begin{array}{l}-0.98 * * * \\
(0.28)\end{array}$ \\
\hline Single & $\begin{array}{l}-1.37 * * * \\
(0.12)\end{array}$ & $\begin{array}{l}-0.86^{* * * *} \\
(0.18)\end{array}$ & $\begin{array}{l}-0.94^{* * *} \\
(0.15)\end{array}$ & $\begin{array}{l}-1.24 * * * \\
(0.13)\end{array}$ & $\begin{array}{l}-1.34^{* * * *} \\
(0.14)\end{array}$ & $\begin{array}{l}-1.73 * * * \\
(0.19)\end{array}$ & $\begin{array}{l}-1.50 * * * \\
(0.29)\end{array}$ & $\begin{array}{l}-1.56 * * * \\
(0.38)\end{array}$ \\
\hline \multicolumn{9}{|c|}{ Labor Force Status } \\
\hline Employed & $\begin{array}{l}-0.44^{* * *} \\
(0.06)\end{array}$ & $\begin{array}{l}-0.20^{* * *} \\
(0.08)\end{array}$ & $\begin{array}{l}-0.25^{* * *} \\
(0.08)\end{array}$ & $\begin{array}{l}-0.44 * * * \\
(0.06)\end{array}$ & $\begin{array}{l}-0.43^{* * *} \\
(0.07)\end{array}$ & $\begin{array}{l}-0.54^{* * *} \\
(0.10)\end{array}$ & $\begin{array}{l}-0.55 * * * \\
(0.14)\end{array}$ & $\begin{array}{l}-0.54 * * * \\
(0.19)\end{array}$ \\
\hline Unemployed & $\begin{array}{l}-0.92 * * * \\
(0.12)\end{array}$ & $\begin{array}{l}-0.26 \\
(0.21)\end{array}$ & $\begin{array}{l}-0.31^{* *} \\
(0.14)\end{array}$ & $\begin{array}{l}-0.69 * * * \\
(0.17)\end{array}$ & $\begin{array}{l}-0.86^{* * * *} \\
(0.12)\end{array}$ & $\begin{array}{l}-1.29 * * * \\
(0.20)\end{array}$ & $\begin{array}{l}-1.34 * * * \\
(0.27)\end{array}$ & $\begin{array}{l}-1.23 * * * \\
(0.38)\end{array}$ \\
\hline $\begin{array}{l}\text { Log Household } \\
\text { Income }\end{array}$ & $\begin{array}{l}0.42^{* * *} \\
(0.05)\end{array}$ & $\begin{array}{l}0.50 * * * \\
(0.07)\end{array}$ & $\begin{array}{l}0.50 * * * \\
(0.06)\end{array}$ & $\begin{array}{l}0.49 * * * \\
(0.05)\end{array}$ & $\begin{array}{l}0.47^{* * * *} \\
(0.06)\end{array}$ & $\begin{array}{l}0.35^{* * * *} \\
(0.07)\end{array}$ & $\begin{array}{l}0.25^{* *} \\
(0.11)\end{array}$ & $\begin{array}{l}0.20^{*} \\
(0.12)\end{array}$ \\
\hline Dummy 2010 & $\begin{array}{l}0.26^{* * *} \\
(0.06)\end{array}$ & $\begin{array}{l}0.10 \\
(0.10)\end{array}$ & $\begin{array}{l}0.13^{*} \\
(0.08)\end{array}$ & $\begin{array}{l}0.16^{* *} \\
(0.07)\end{array}$ & $\begin{array}{l}0.17^{* * * *} \\
(0.08)\end{array}$ & $\begin{array}{l}0.32 * * * \\
(0.10)\end{array}$ & $\begin{array}{l}0.37 * * * \\
(0.12)\end{array}$ & $\begin{array}{l}0.43 * * * \\
(0.16)\end{array}$ \\
\hline Dummy 2012 & $\begin{array}{l}0.29^{* * *} \\
(0.06)\end{array}$ & $\begin{array}{l}0.14 \\
(0.09)\end{array}$ & $\begin{array}{l}0.18 * * * \\
(0.07)\end{array}$ & $\begin{array}{l}0.24 * * * \\
(0.06)\end{array}$ & $\begin{array}{l}0.24 * * * \\
(0.07)\end{array}$ & $\begin{array}{l}0.28^{* * * *} \\
(0.09)\end{array}$ & $\begin{array}{l}0.34 * * * \\
(0.12)\end{array}$ & $\begin{array}{l}0.48 * * * \\
(0.16)\end{array}$ \\
\hline (Pseudo) $\mathbf{R}^{2}$ & 0.11 & 0.05 & 0.06 & 0.06 & 0.06 & 0.06 & 0.08 & 0.08 \\
\hline $\mathbf{N}$ & 40699 & 40699 & 40699 & 40699 & 40699 & 40699 & 40699 & 40699 \\
\hline
\end{tabular}

Source: Authors' computations using 2008, 2010 and 2012 Turkish Health Survey

$* * *$ indicates $1 \%$ level of significance, $* *$ indicates $5 \%$ level of significance, *indicates $1 \%$ level of signific 
Table 3 shows that there is an insignificant relationship between an individual's years of schooling and his/her BMI level at the $5^{\text {th }}$ and $10^{\text {th }}$ Quantiles. But, starting from the $25^{\text {th }}$ Quantile we observe a strong negative association between years of schooling and BMI. The magnitude of the relationship rises systematically from the $25^{\text {th }}$ to the $90^{\text {th }}$ Quantile. It decreases slightly at the $95^{\text {th }}$ Quantile (from 0.22 to 0.19 ). The result is consistent with the findings of Costa-Font et al. (2009), who also examine the association between an individual's BMI level and education using QR analysis for Italy and Spain. Similar to our study Costa-Font et al. also find the negative relationship between an individual's years of schooling and BMI is highest in absolute value at highest quantiles of BMI for both countries.

The association between the logarithm of household income and an individual's BMI level is positive and significant at all quantiles, In general, our results suggest that people with higher income levels have higher BMI levels. In fact, this is an expected result since people can spend more on various healthy or unhealthy food if their income is high. In contrast, Villar and Quintana-Domeque (2009) find mixed evidence regarding this issue for various European Union countries. ${ }^{[10]}$ Their results do not suggest a significant relationship between household income and BMI for men, but they find a negative relationship for women. They state that the difference between men and women mainly comes from the self-labor earnings for women.

The relationship between gender and BMI is ambiguous across the quantiles. At lower quantiles of BMI, men have higher BMI levels. For instance, at median, men tend to have higher BMI levels, which confirms the fact that men are more likely to be overweight compared to women. However, at the highest quantiles of BMI $\left(75^{\text {th }}, 90^{\text {th }}\right.$ and $95^{\text {th }}$ Quantiles) women have higher BMI levels. The magnitude of the gender effect increases in absolute values across the quantiles if the individual is female. This result indicates that prevalence of obesity is higher among women in Turkey consistent with the descriptive statistics results obtained from our data set, where we observed that 17 per cent of men and 26 per cent of women are considered obese in our data set.

The relationship between age and BMI level is concave as is the case in the OLS results. The magnitude of the relationship between age and BMI increases monotonically across the quantiles. This implies that the probability of becoming overweight or obese increases with age. This finding is consistent with Costa-Font et al. (2009) and Villar and Quintana-Domeque (2009)'s studies of obesity in European countries. ${ }^{[11]}$

Both OLS and QR regression analysis results suggest that people who live in urban areas have significantly higher BMI levels than people who live in rural areas. For instance, at the $50^{\text {th }}$ and $75^{\text {th }}$ Quantiles, living in urban areas has a positively significant effect on an individual's BMI. Hence, we can infer that being overweight is more prevalent in urban areas. However, at the $90^{\text {th }}$ and $95^{\text {th }}$ Quantiles, the association between place of residence and an individual's BMI becomes insignificant, indicating that the

\footnotetext{
${ }^{[10]}$ The countries they study are Austria, Belgium, Denmark, Finland, Greece, Ireland, Italy, Portugal and Spain.

${ }^{[11]}$ We interact the variables of age and education and replicate QR estimation. However, the results do not provide a significantly robust association between the interaction term and individual's BMI level.
} 
prevalence of obesity does not differ between urban and rural areas. Sedentary life styles and unhealthy food consumption are observed more often in urban areas. These can lead to increases in obesity rates in urban areas. However, we should note that the consumption of foods with high calories such as white bread, biscuits, butter, sugar, honey and molasses is higher in rural areas. ${ }^{[12]}$ Therefore, it is not surprising that the occurrence of obesity does not significantly differ between urban and rural areas at the top quantiles of BMI.

Regarding marital status the results suggest that single people have significantly lower BMI levels relative to widowed/divorced individuals. The coefficient of being single increases systematically in absolute value with the level of BMI, rising from 0.86 in the $5^{\text {th }}$ Quantile to 1.56 in the $95^{\text {th }}$ Quantile. There is no significant relationship between being married and BMI levels in lower quantiles. However, starting from the $50^{\text {th }}$ Quantile married people have significantly lower BMI levels than widowed/divorced individuals. The association between being married and BMI level rises monotonically from the $50^{\text {th }}$ to the $95^{\text {th }}$ Quantile. However, the impact of being married is not as strong as that of being single on an individual's BMI levels. Costa-Font et al. (2009) find similar results for Spain and Italy.

We do not observe a significant association between being unemployed and an individual's BMI level at the $5^{\text {th }}$ Quantile. At the $10^{\text {th }}$ Quantile, being unemployed leads to a 31 per cent decrease in the BMI level. The impact of being unemployed raises monotonically from the $10^{\text {th }}$ Quantile and reaches its highest value (1.34 in absolute value) in the $90^{\text {th }}$ Quantile. The impact of being employed also increases systematically starting from the $5^{\text {th }}$ Quantile and the magnitude of the negative relationship between being employed and BMI level is highest at the $90^{\text {th }}$ Quantile (54 per cent). In short, our findings imply that both the employed and the unemployed people have significantly lower BMI levels than inactive people. These results are consistent with those of CostaFont et al. (2009) in Italy and Spain.

Finally, we find both year dummies are positive and significant across all quantiles. The magnitudes of both the 2010 dummy and the 2012 dummy increase monotonically from the lower to upper quantiles. Further, there has been a larger increase in the BMI in all of the quantiles in 2012 than in 2010, except in the $90^{\text {th }}$ Quantile. This result indicates that in Turkey, the prevalence of obesity has been increasing over time.

We then replicate $\mathrm{QR}$ analysis, by using education level dummies instead of an individual's complete years of schooling, since using simple dummy variables for each education category would be more flexible and potentially more informative regarding the association between an individual's education and BMI levels. We have four different education categories in the new analysis. "Primary or less" equals 1 if the individual is illiterate, non-educated or has a primary school degree; "Middle school" equals 1 if the individual has graduated from middle school; "High School" equals 1 if the individual has a high school degree and "University or higher" equals 1 if the individual has a university or postgraduate degree. In our analysis, the base category

${ }^{[12]}$ Source: Turkish Nutrition and Health Survey 2010. 
is "university or higher degree" as this allows us to compare less-educated individuals to university graduates. Our results clearly suggest that individuals with less education have higher BMI levels compared to individuals with university or postgraduate degrees. The marginal effects of all education levels (except high school degree) monotonically increase in absolute value across quantiles. In addition, the marginal effect in absolute values is the highest for individuals with degrees from primary school or less. Therefore, being overweight or obese is more common among less-educated individuals. QR estimation results regarding the other covariates do not change significantly in this new specification. Table 4 presents the new estimation results for education categories across different quantiles of BMI.

Table 4

Quantile Regression Results (Education Control: Education Level Dummies)

\begin{tabular}{|c|c|c|c|c|c|c|c|}
\hline & (1) & (2) & (3) & (4) & (5) & (6) & (7) \\
\hline $\begin{array}{l}\text { Education } \\
\text { Categories }\end{array}$ & Q5 & Q10 & Q25 & Q50 & Q75 & Q90 & Q95 \\
\hline $\begin{array}{l}\text { Primary School } \\
\text { or less }\end{array}$ & $\begin{array}{c}0.532^{* * *} \\
(0.120)\end{array}$ & $\begin{array}{c}0.763^{* * *} \\
(0.101)\end{array}$ & $\begin{array}{c}0.977 * * * \\
(0.0816)\end{array}$ & $\begin{array}{l}1.272 * * * \\
(0.0860)\end{array}$ & $\begin{array}{c}1.510^{* * *} \\
(0.106)\end{array}$ & $\begin{array}{c}1.631^{* * *} \\
(0.157)\end{array}$ & $\begin{array}{c}1.792 * * * \\
(0.231)\end{array}$ \\
\hline Middle School & $\begin{array}{c}0.403 * * * \\
(0.137)\end{array}$ & $\begin{array}{c}0.535 * * * \\
(0.111)\end{array}$ & $\begin{array}{l}0.717^{* * *} \\
(0.0958)\end{array}$ & $\begin{array}{c}0.796^{* * *} \\
(0.103)\end{array}$ & $\begin{array}{c}0.958 * * * \\
(0.129)\end{array}$ & $\begin{array}{c}0.920 * * * \\
(0.215)\end{array}$ & $\begin{array}{c}1.179^{* * * *} \\
(0.293)\end{array}$ \\
\hline High School & $\begin{array}{c}-0.0144 \\
(0.120)\end{array}$ & $\begin{array}{l}0.194 * \\
(0.103)\end{array}$ & $\begin{array}{c}0.248^{* * *} \\
(0.0844)\end{array}$ & $\begin{array}{l}0.381 * * * \\
(0.0872)\end{array}$ & $\begin{array}{c}0.545^{* * * *} \\
(0.121)\end{array}$ & $\begin{array}{c}0.370 * * \\
(0.165)\end{array}$ & $\begin{array}{l}0.433 * \\
(0.247)\end{array}$ \\
\hline Observations & 40,699 & 40,699 & 40,699 & 40,699 & 40,699 & 40,699 & 40,699 \\
\hline
\end{tabular}

Source: Authors' computations using 2008, 2010 and 2012 Turkish Health Surveys

*** indicates $1 \%$ level of significance, **indicates $5 \%$ level of significance, *indicates $1 \%$ level of significance

We also control for other covariates that we use in the previous specification (Table 3). Since the results do not significantly differ from the previous specification, we do not present the results regarding the other covariates in Table 4.

In short, our results establish a clear association between an individual's BMI level and various socio-economic and demographic factors. The mechanism behind these correlations may be explained by the determining factors of related health behaviors such as eating habits and physical activity. Tansel and Karaoglan (2014) examine the determinants of fruit and vegetable consumption as well as exercise by using the same waves of the THS data set and controlling the same set of independent variables as this study. They conclude that an individual's education level is the most relevant factor in explaining the variation in these health behaviors. Their results suggest that individuals with higher levels of education are more informed about the benefits of fruit and vegetable consumption. In addition, their findings indicate that there exists a positive association between schooling and exercise. Therefore, we can infer that more educated individuals have healthier life styles, and this may help to explain why they tend to have normal ranges of BMI. 


\section{Conclusion}

In this paper, first, we investigate the determinants of BMI by using QR in order to see how education as well as other factors affect the individual's BMI level at different quantiles of the distribution of BMI. QR results suggest that an individual's BMI decreases with additional years of schooling. The negative relationship between years of schooling and BMI increases monotonically from the $25^{\text {th }}$ to the $90^{\text {th }}$ Quantile and the effect is rather still high at the top quantile of the BMI. Therefore, we can conclude that people with higher levels of education are more aware of the dangers of obesity.

Quantile regression results also suggest that women tend to be more obese than men as the gender coefficient is found to be negative at the highest quantiles of BMI. However at median, we observe that men have higher BMI levels, indicating that men are more likely to be overweight. These results are consistent with descriptive statistics on Turkey, which state that being overweight is more common among men, whereas obesity is more common among women. We also find that age and BMI have an inverted U-shape relationship implying that individuals are more likely to be overweight or obese as they get older. Next, we observe that, in general, people living in urban areas tend to have higher BMI levels. For instance, at the $50^{\text {th }}$ and $75^{\text {th }}$ Quantiles, living in an urban region has a positively significant effect on an individual's BMI, indicating that being overweight is more common in urban areas. However, we conclude that the prevalence of obesity is not significantly different between urban areas and rural areas, since the relationship between place of residence and BMI is found to be insignificant at the top two quantiles of BMI. Single individuals have significantly lower BMI levels relative to widowed/divorced. The negative relationship between being single and BMI level increases systematically in absolute value across the quantiles of BMI. The relationship between being married and BMI is also negative but smaller than among those who are single. Inactive individuals have significantly higher BMI levels compared to employed and unemployed individuals and the negative relationship between labor force participation and BMI level gradually increases in absolute value across the quantiles of BMI. Our results provide robust evidence that an individual's BMI level and household income are positively associated with each other, since the positive association between them, although it undergoes gradual decline, remains valid across quantiles of BMI. Lastly, our findings indicate that the prevalence of obesity has increased over time in Turkey, as the positive coefficients of year dummies for 2010 and 2012 increases across the quantiles of the BMI. Hence, QR results reveal that obesity is becoming a serious health problem in Turkey over time just as in developed countries.

Our results clearly support the fact that higher levels of education are negatively associated with higher BMI levels. This result is consistent with Siddiqui and Donato (2016), who conduct a similar study for India, a developing country. Their findings also suggest that women are more likely to be obese/overweight in India; however, they stress that as the education level of women increases, the probability of being obese/ overweight declines. They highlight the important impact of education on an individual's awareness of the dangers of having high BMI. Therefore, one can conclude that public 
health policies (for instance, campaigns against obesity or promoting healthy nutrition) will be more effective if an individual's education level increases. The mechanism behind the negative association between an individual's years of schooling and BMI level can be explained by the determining factors of related health behaviors such as eating habits and physical activity. Tansel and Karaoglan (2014) conclude that individuals with higher levels of education are more informed about the benefits of fruit and vegetable consumption. In addition, their findings suggest that higher levels of education increase the probability of doing regular exercise. Therefore, one can conclude that lengthier schooling leads to healthier life styles and this may lead to normal ranges of BMI.

\section{References}

Aekplakorn, W., Inthawong, R., Kessemboon, P., Sangthong, R., Chariyalertsak S., Putwatana P., and Taneepanichskul, S. (2014). "Prevalence and Trends of Obesity and Association with Socioeconomic Status in Thai Adults: National Health Examination Surveys, 1991-2009," Journal of Obesity, 14: 1-8.

Ankara, H.G. (2016). "Inequality Analyses of Obesity in Turkey," International Journal of Social Science and Humanity, 6: 742-755.

Arendt, J. N. (2005). "Does Education Cause Better Health? A Panel Data Analysis Using School Reforms for Identification," Economics of Education Review, 24(2): 149-160.

Atella, V., Pace, N. and Vuri, D. (2008). "Are Employers Discriminating with respect to Weight?: European Evidence Using Quantile Regression," Economics and Human Biology, 6 (3): 305-329.

Brunello, G., Fabbri, D. and Fort, M. (2013). "The Causal Effect of Education on Body Mass: Evidence from Europe," Journal of Labor Economics, 31(1): 195-223.

Cameron, C.A., and Trivedi, P.K. (2005). Microeconometrics: Methods and Applications. New York: Cambridge University Press.

Center of Disease Control (CDC): https://www.cdc.gov/nchs/data/databriefs/db219.pdf (Accessed on December 2016).

Cesur, R., Dursun, B. and Mocan, N. (2014). "The Impact of Education on Health and Health Behavior in a Middle-Income, Low-Education Country," National Bureau of Economic Research (NBER) Working Paper No. 20764. Cambridge, MA.

Chou, S. Y., Grossman, M. and Saffer, H. (2002). "An Economic Analysis of Adult Obesity: Results from the Behavioral Risk Factor Surveillance System," Journal of Health Economics, 23(3): 565-587.

Costa-Font, J., Fabbri, D. and Gil, J. (2009). "Decomposing Body Mass Index Gaps between Mediterranean Countries: A Counterfactual Quantile Regression Analysis," Economics and Human Biology, 7(3): 351-365.

Cutler, D. M., Glaeser, E.L. and Shapiro, J.M. (2003). "Why Have Americans Become More Obese?," The Journal of Economic Perspectives, 17(3): 93-118.

Dinsa, G.D., Goryakin, Y., Fumagalli, E., Suhrckle, M. (2012). "Obesity and Socioeconomic Status in Developing Countries: A Systematic Review," Obesity Reviews, 13: 1067-1079.

Erem, C., Arslan, C., Hacıhasanoğlu, A., Değer, O., Topbaş, M., Ukinc, K., Ersöz, H.Ö., and Telatar, M. (2004). "Prevalence of Obesity and Associated Risk Factors in a Turkish Population (Trabzon City, Turkey)," Obesity Research, 12(7): 1117-1127. 
Fernald, Lia C. H. (2007). "Socioeconomic Status and Body Mass Index in Low-Income Mexican Adults," Social Science and Medicine, 64: 2030-2042.

Hatemi, H., Yumuk, V.D., Turan, N., and Arık, N. (2003). "Prevalence of Overweight and Obesity in Turkey," Metabolic Syndrome and Related Disorders, 1(4): 285-290.

Jürges, H., Reinhold, S. and Salm, M. (2011). "Does Schooling Affect Health Behavior? Evidence from Educational Expansion in Western Germany," Economics of Education Review. 30: 862-872.

Kemptner, D., Jürges, H. and Reinhold, S. (2011). "Changes in Compulsory Schooling and the Causal Effect of Education on Health: Evidence from Germany," Journal of Health Economics, 30(2): 340-354.

Koenker, R., and Bassett, G. (1978). "Regression Quantiles," Econometrica: Journal of the Econometric Society, 46(1): 33-50.

Koenker, R., and Hallock, K. (2001). "Quantile Regression: An Introduction,” Journal of Economic Perspectives, 15(4): 43-56.

Lleras-Muney, A. (2005). "The Relationship between Education and Adult Mortality in the U.S.," Review of Economic Studies, 72 (1): 189-221.

Philipson, T. J., and Posner, R. A. (2003). "The Long-Run Growth in Obesity as a Function of Technological Change," Perspectives in Biology and Medicine, 46(3): 87-107.

------, (2008). "Is the Obesity Epidemic a Public Health Problem? A Review of Zoltan J. Acs and Alan Lyles's Obesity, Business and Public Policy," Journal of Economic Literature, 46(4): 974-982.

Rashad, I. and Grossman, M. (2004). "The Economics of Obesity," Public Interest, 156: 104-113.

Siddiqui, Z., and Donato, R. (2015). "Overweight and obesity in India: policy issues from an exploratory multi-level analysis," Health Policy and Planning, 31(5): 582-591.

Stewart, S. T., Cutler, D. M. and Rosen, A. B. (2009). "Forecasting the Effects of Obesity and Smoking on US Life Expectancy," New England Journal of Medicine, 361(23): 2252-2260.

Tansel, A., and Karaoğlan, D. (2014). "Health Behaviors and Education in Turkey," Institute for the Study of Labor (IZA) Discussion Paper No: 8262. Bonn, Germany.

------, (2016). "The Causal Effect of Education on Health Behaviors: Evidence from Turkey," Institute for the Study of Labor (IZA) Discussion Paper No: 10020. Bonn, Germany.

Turkish Nutrition and Health Survey, 2010 (http://www.sagem.gov.tr/TBSA_Beslenme_Yayini.pdf) (Accessed on April 2015).

Villar, J.G., and Quintana-Domeque, C. (2009). "Income and Body Mass Index in Europe," Economics and Human Biology, 7(1): 73-83.

Webbink, D., Martin, N.G. and Visscher, P M. (2010). "Does Education Reduce the Probability of Being Overweight? ," Journal of Health Economics, 29(1): 29-38.

Yumuk, V. D. (2005). "Prevalence of Obesity in Turkey,” Obesity Reviews, 6(1): 9-10. 